Published as: H.T. Nguyen and J.M. Pearce, "Estimating Potential Photovoltaic Yield with r.sun and the Open Source Geographical

Resources Analysis Support System” Solar Energy 84, pp. 831-843, 2010. http://dx.doi.org/10.1016/j.solener.2010.02.009

\title{
Estimating Potential Photovoltaic Yield with r.sun and the Open Source Geographical Resources Analysis Support System
}

\author{
H.T. Nguyen ${ }^{\mathrm{a}}$ and J.M. Pearce $\mathrm{a,b}$
}

\begin{abstract}
:
The package r.sun within the open source Geographical Resources Analysis Support System (GRASS) can be used to compute insolation including temporal and spatial variation of albedo and solar photovoltaic yield. A complete algorithm is presented covering the steps of data acquisition and preprocessing to post simulation whereby candidate lands for incoming solar farms projects are identified. The optimal resolution to acquire reliable solar energy outputs to be integrated into PV system design software was determined to be 1 square $\mathrm{km}$. A case study using the algorithm developed here was performed on a North American region encompassing fourteen counties in Southeastern Ontario. It was confirmed for the case study that Ontario has a large potential for solar electricity. This region is found to possess over 935,000 acres appropriate for solar farm development, which could provide 90 GW of PV. This is nearly 60\% of Ontario's projected peak electricity demand in 2025 . The algorithm developed and tested in this paper can be generalized to any region in the world in order to foster the most environmentally-responsible development of large-scale solar farms.
\end{abstract}

Keywords: GRASS GIS; photovoltaic; renewable energy; solar energy; solar irradiation modeling

\section{Introduction}

The Eastern wisdom that mankind will reap great harvests from being able to predict and utilize the weather, especially the sun, has never been so applicable as in this 'renewable energy era' described in the communiqué from the G8 Leaders' Summit in 2001 (Sims, 2003). The current global economies are: (i) carbon locked-in (Unruh 2000, 2002), (ii) vulnerable to volatile energy prices (Kilian 2008; Pindyck 1999), (iii) dependent on depleting and increasingly technology- and capital-intensive carbonbased fuel reserves (IEA, 2008; Asif \& Muneer, 2007) and (iv) divided over the geopolitical tensions surrounding these fossil fuels (Asif \& Muneer, 2007; Keppler, 2007). Most importantly, to achieve an acceptable level of global atmospheric carbon dioxide $\left(\mathrm{CO}_{2}\right)$ concentration (Enting et al., 1994; Nakocenovic \& Swart, 2000) and thus to begin radically reducing greenhouse gas emissions, large cuts in fossil fuel combustion are necessary (Watson et al., 1996; Houghton et al., 1997; WBGU, 2009) .

The urgency of reducing emissions in a sustainable, economically and environmentally-acceptable and equitable manner, while producing vast quantities of energy to maintain and enhance our standard of living has made it imperative to pursue sustainable renewable energy technologies, namely wind, geothermal, biomass and solar (WBGU, 2009; Pearce, 2002; Metz et al., 2007). Of these technologies, photovoltaic (PV) technology has been found to be technologically robust, scalable, geographically dispersed and posses an enormous potential for producing a sustainable source of energy (Pearce, 2002; Zekai, 2004).

The policy mechanisms used to support accelerated deployment of solar and other renewable energy sources have grown to focus largely on Feed-in tariffs (FIT)s which provide a premium for non-carbon

a Department of Mechanical and Materials Engineering, Queen's University, Kingston, Ontario, K7L 3N6 Canada.

b Corresponding author: 60 Union Street, Kingston, Ontario, K7L 3N6 Canada, phone: 613-533-3369,

pearce@me.queensu.ca 
Published as: H.T. Nguyen and J.M. Pearce, “Estimating Potential Photovoltaic Yield with r.sun and the Open Source Geographical Resources Analysis Support System” Solar Energy 84, pp. 831-843, 2010. http://dx.doi.org/10.1016/j.solener.2010.02.009

intensive electricity generation. Countries who have adopted FITs have the largest growth rates in renewable energy technology deployment, among which Japan, Germany and Spain are the pioneers (REN21, 2009). The province of Ontario, Canada has recently committed to phasing out the use of all coal-fired plants by 2014 (OPA, 2009). To reach this goal, the Green Energy and Green Economy Act 2009 (REN21, 2009), which includes provisions for a new FIT renewable energy incentive program (OPA, 2009b), was passed in May 2009. Under this plan, owners of renewable energy technologies will enter into a 20-year fixed-term contracts with the Ontario Power Authority (OPA) whereby they will be paid a fixed amount per unit energy provided to the electrical grid. The tariff prices are set on a sliding scale such that they provide a greater economic incentive for small-scale, rooftop-mounted solar PV installations over large, ground-mounted systems in order to equalize the rate of return (Wiginton et al., 2010). For residential solar PV applications $>10 \mathrm{~kW}$ in size, owners will be paid CAD\$0.802 per $\mathrm{kW}$ (OPA, 2009b). However, it is expected that the greatest magnitude of solar PV electricity will be provided by large $>10 \mathrm{MW}$ solar farms made up of ground mounted PV, which will be paid CAD\$0.43 per kW-hr (OPA, 2009b). This level of incentive provides the potential for large profits in addition to providing the Ontario grid with large quantities of solar-generated electricity. The relatively abundant bare land in Ontario creates a need for reliable information regarding local climate, topography and solar irradiation budgets to facilitate the installation of these projects (Carriona et al., 2008a). Any region wishing to institute a FIT that allows ground-mounted PV would have similar needs.

This paper addresses the need to provide data to engineer large-scale new solar PV farms. Specifically it explores a case study in the Renewable Energy Region (RER) ${ }^{1}$ of south-eastern Ontario, offering an algorithm that is applicable to other regions in Ontario and throughout the world, which utilizes open source and free software tools and data. Algorithms necessary to overcome deficiencies in previous work on the use of r.sun - one of the utilities of the open source Geographical Resources Analysis Support System (GRASS) GIS software package are provided. Here r.sun is used to compute insolation, including temporal and spatial variation of albedo. The optimal resolution to acquire reliable solar energy outputs to be integrated into PV system design software is determined. Finally, for the case study of the RER, candidate areas for new large scale solar farms in southeastern Ontario are identified.

\section{Background}

Solar radiation is affected by atmospheric conditions such as optical thickness and cloud cover; topographical characteristics such as latitude, slope, aspect and shadow cast; ecological processes such as snow melting, evapo-transpiration; and human activities. In most cases, insolation is the result of the interactions between all these factors (Duffie \& Beckman, 1991; Hofierka \& Suri, 2002). To make modeling of solar radiation even more challenging, insolation data sets are expensive to collect and in Canada, as well as in other countries (with the exception of the United States and the European Union), few meteorological stations record such data (Hofierka \& Suri, 2002; McKenney et al., 2008).

Approaches used to determine solar radiation over a large geographic regions often derive spatial databases of solar radiation using different interpolation techniques e.g. spline functions (Hutchison et al., 1984), kriging or co-kriging (Beyer et al., 1997; D'Agostino \& Zelenka, 1992; Zelenka, 1992, 1994), or calculate solar irradiance directly from meteorological geostationary satellites (e.g. the

1This paper is part of an extensive project to model the potential to create a Renewable Energy Region (RER) in southeastern Ontario. The RER was designated by the Queen's Institute for Energy and Environmental Policy to comprise the following fourteen counties: Stormon, Dundas \& Glengarry; Haliburton; Peterborough; Ottawa; Lanark; Lennox \& Addington; Hastings; Renfrew; Kawartha Lakes; Northumberland; Prince Edward; Frontenac; Leeds \& Grenville and Prescott \& Russell (Mabee et al., 2009). 
Published as: H.T. Nguyen and J.M. Pearce, “Estimating Potential Photovoltaic Yield with r.sun and the Open Source Geographical Resources Analysis Support System” Solar Energy 84, pp. 831-843, 2010. http://dx.doi.org/10.1016/j.solener.2010.02.009

European based Meteosat and the American owned Geostationary Operational Environmental Satellite) (Cebecauer et al., 2007; Rigollier et al., 2004). A new generation of satellites (e.g. Meteosat $2^{\text {nd }}$ Generation) and new processing models (e.g. Heliosat-3) have improved the temporal and spatial resolutions (MSG, 2002), while retaining the advantage of providing data covering vast territories (Suri et al., 2007). The third approach is to couple the geographical information systems (GIS) functions with existing models and run it using Fortran or Matlab (Chrysoulakis et al., 2004; Zaksek et al., 2005).

Examples of solar radiation and climatology databases that extend beyond the national level and offer free online and offline access are the European Solar Radiation Data ${ }^{2}$ (SoDA) and RETScreen/ NASA Surface Solar Energy ${ }^{3}$ (SSE). However, despite broad geographical coverage they suffer from low resolution. It is more difficult to find readily made insolation maps of reasonably good quality. Those for Africa and selected developing countries were accomplished upon funding from the European Commission $^{4}$ and the United Nations Environment Program (UNEP) ${ }^{5}$ respectively and they mostly appear on the web as simple images, which are of limited value for further regional research and analysis. For Canada, insolation maps exist in the Natural Resources Canada's Photovoltaic System Design Manual, NASA SSE worldwide maps and at the Great Lakes Forestry Centre (McKenney et al., 2008). Again these resources suffer from low resolution with the finest being 300 arc seconds $(\sim 10$ $\mathrm{km})$, which is much larger than any existing solar farm. The level of accuracy of all three approaches has been shown to be quite similar and reliable, which makes the choice of an appropriate method rest on available data, required precision, and scale/time frame (McKenney et al., 2008).

Solar radiation models integrated within GIS have been found to eliminate the complexity of programming GIS functions into mathematical models (Hokierka \& Suri, 2002). They provide fast and accurate computation of radiation over large regions while still considering the effect of local geography. Solar radiation models within GIS are also able to incorporate environmental and socioeconomical data and generate scenarios of interest to policy makers. The efficiency, flexibility and other capabilities of various models (e.g. Solar Analyst, SolarFlux, Solei, and SRAD) have been discussed extensively to show the need for a new model (Suri et al., 2005). Here r.sun will be the main tool utilized in this paper. The package estimates beam, diffuse and reflected components of the clearsky and real-sky global irradiance/irradiation on horizontal or inclined surfaces. The total daily irradiation (Wh per $\mathrm{m}^{2}$ ) is computed by the integration of the irradiance values (W per $\mathrm{m}^{2}$ ) calculated at regular time intervals over the day. For each time-step, the computation accounts for sky obstruction by local terrain features (hills or mountains), calculated from the Digital Elevation Model. For the model equations and applied approach in more detail, see Hofierka \& Suri (2002). The application of r.sun has been demonstrated in a few specific regions in the past (Suri et al., 2007; Huld et al., 2002; Huld et al., 2005).

\section{Method}

2 http://www.soda-is.com/

3 http://eosweb.larc.nasa.gov/sse/

4 http://re.jrc.ec.europa.eu/pvgis/countries/africa.htm

5 United Nations Environment Program. (2003). Results of Solar Resource Assessments in the UNEP/SWERA

Project. Paris: SWERA Project Manager. 
Published as: H.T. Nguyen and J.M. Pearce, "Estimating Potential Photovoltaic Yield with r.sun and the Open Source Geographical

Resources Analysis Support System” Solar Energy 84, pp. 831-843, 2010. http://dx.doi.org/10.1016/j.solener.2010.02.009

The methodology used in this paper is divided into three parts: (1) pre-simulation, (2) simulation and (3) post-simulation. Pre-simulation details data input acquisition and manipulation to meet r.sun's parameters, which were often lightly treated, but are often the most time consuming and challenging part of any GIS related project. Therefore pre-simulation steps will be presented here in a transparent fashion to ease the work of upcoming PV deployment projects and to make the methodology as omniapplicable as possible. Simulation is the running of the package itself. Post-simulation will include calculating of an annual yields based on monthly estimates and optimal siting for candidate solar parks/farms. Due to the complex nature of modeling radiation and the relatively unfamiliarity of the scientific community outside Europe with r.sun to ensure precision many steps in the workflow as seen in Figure 1 were carried out on the proprietary ArcMap software version 9.3. However, the GRASS counterpart for a step is included in order to allow for greater access following recent developments in open access and open source software mapping packages to support energy and environmental goals (Pearce, et al., 2007; Doyle and Pearce, 2009).

\subsection{Pre-simulation}

The required data inputs include:

- Census Subdivisions (CSD) of the 14 counties in the RER

- Soil types for forestry

- Soil types for agriculture

- Land use classification (exclusive of agriculture)

- Digital Elevation Model (DEM)

- Slope/ inclination: the angle between the plane of the surface in question and the equator plane

- Aspect/ orientation: the surface azimuth angle, the deviation of the projection of the normal to the plane in question on the equator plane from the local meridian

- Latitude: the angular location north or south of the equator's plane

- Albedo: the ratio of diffusely reflected radiation on a surface to its incident radiation

- Mean days and corresponding angular position of the sun

- Linke turbidity: a convenient approximation to model the atmospheric absorption and scattering of the solar radiation under clear skies

- Ground-measured values of global horizontal irradiation (GHI)

- Clear sky index Kc: ratio of the global horizontal irradiance to the global horizontal irradiance under clear sky conditions ${ }^{6}$. It is important not to confuse and hence misuse this definition with those for insolation clearness index and clear sky insolation clearness index ${ }^{7}$.

For the case study of the RER the following data sets were use. Within the list of available projections for Canada only the Lambert Conformal Conic (LCC) NAD 1983 MNR Ontario is boundary- 
Published as: H.T. Nguyen and J.M. Pearce, "Estimating Potential Photovoltaic Yield with r.sun and the Open Source Geographical Resources Analysis Support System” Solar Energy 84, pp. 831-843, 2010. http://dx.doi.org/10.1016/j.solener.2010.02.009

compatible to the region of study. Hence even though it is not area-preserved (i.e. reflecting true areas from ground measurement) it was used here. Henceforth, unless otherwise indicated, all steps in the workflow are under this LCC NAD83 MNR Ontario projection.

3.1.1 Census subdivision information: A Population Ecumene Census Division Cartographic Boundary File is provided free of charge by Statistics Canada, which is up-to-date according to the 2006 Census and can be downloaded ${ }^{8}$ as a vector shapefile. The file is used throughout the simulation to constrain the modeling within the RER and hence reduce computational time.

3.1.2 Soil classification: Thematic soil classification for forestry, agriculture and civic land use is available free of charge from GeoGratis ${ }^{9}$, where Natural Resources Canada develops Canadian Land Inventory (CLI) files for distribution. Accordingly the RER takes up tiles numbered 031b through 031l (with the exception of 031i and 031j being in Quebec). Unfortunately, data was unavailable for part of Prince Edwards County.

From the accompanying documents for agriculture the soil classes that are of interest are 6 and 7 , where soils are either capable only of producing perennial forage crops and improvement practices are not feasible or soils have no capacity for arable culture or permanent pasture. Forestry classes 6 and 7 were also chosen, as they include lands having severe limitations to the growth of commercial forests or those having severe limitations that preclude the growth of commercial forests. Since the scope of this paper is in radiation modeling and preliminary selection of candidate land for new solar parks more in-depth ecological information was set aside, and hence the subclasses were not used. For land use, the classes that attracted attention were $\mathrm{K}$ - areas of natural grasslands, sedges, herbaceous plants and abandoned farmland whether used for grazing or not, $\mathrm{U}$ - nonproductive woodlands, S - sandy unproductive lands that do not support vegetation and L - rocky unproductive surfaces that do not support vegetation. Since hardness of a surface can be an issue for grounding and hole mounting (REC Solar, 2009), only K and U classified lands are extracted. Thus only land areas which overlapped the 3 classification schemes were considered for solar PV farm development (i.e. classified from the forestry classes 6 and 7 and agriculture 6 and 7 and land use K and U).

3.1.3 Digital Elevation Model:Two different DEMs (GTOPO30 ${ }^{10}$ and SRTM3 ${ }^{11}$ ) were used for this study, suggested by Cebecauer et al. (2007) that the decrease of DEM resolution from $100 \mathrm{~m}$ to $3000 \mathrm{~m}$ may potentially lead to overestimation of the regional means of the yearly electricity yield by $8.2 \%$ for the former system and $15.2 \%$ for the latter one. GTOPO30 is a global DEM, where elevations are regularly spaced at 30-arc seconds (GTOPO30). SRTM30 is a near-global digital elevation model comprising of a combination of data from the Shuttle Radar Topography Mission, flown in February, 2000 and the U.S. Geological Survey's GTOPO30 dataset (SRTM3). SRTM30 is formatted and organized in a fashion that mimics the GTOPO30 convention so software and GIS systems that work with GTOPO30 should also work with SRTM30. Note that 30m DEMs were also available from SRTM1 for part of the RER and also offered from Queen's University Map Library, however to minimize computational time $1 \mathrm{~km}$ and 90m DEMs were selected first for simulation (GEO326G University of Texas).

r.sun 'prefers' all input rasters to be formatted as ESRI ascii grids. A separate import function within GRASS GIS version 6.3.0 is dedicated to import ESRI ascii grids into a workspace, the configurations

8 http://geodepot.statcan.gc.ca/2006/040120011618150421032019/16151605032113051405_05-eng.jsp

9 http://geogratis.cgdi.gc.ca/CLI/index_forestry.html

$10 \mathrm{ftp}: / /$ edcftp.cr.usgs.gov/pub/data/gtopo30/global/

11 http://dds.cr.usgs.gov/srtm/version2_1/SRTM3/North_America/ 
Published as: H.T. Nguyen and J.M. Pearce, "Estimating Potential Photovoltaic Yield with r.sun and the Open Source Geographical Resources Analysis Support System” Solar Energy 84, pp. 831-843, 2010. http://dx.doi.org/10.1016/j.solener.2010.02.009

(projection, boundary, north-east and south-west resolutions) of which were set to be compatible with the input using Region settings. It is worth noting that unless the region for the workspace and input are compatible in terms of the above configurations no output will be given.

3.1.4 Turbidity coefficient:The Linke turbidity factor (TL, often normalized at an air mass $=2$ to reduce its dependence on air mass (Ineichen \& Perez, 2002)) refers to the overall spectrally integrated attenuation, which includes the presence of gaseous water vapor and aerosols. On the other hand, Angstrom and Schiepp turbidity coefficients are obtained from spectral measurements and indicate only the amount of aerosols in the atmosphere (Louche et al., 1986). The larger TL, the less transparent is the sky and hence the larger the attenuation of the radiation. A worldwide database of the Linke turbidity factor as well as the database for elevation can be obtained at Les Presses, Ecole des Mines de Paris.

A byproduct of data downloaded from CLI is a point shapefile of 99 towns and cities within the RER. Once tabulated the geographic longitude and latitude values of each location can be calculated, which were then used to query the corresponding monthly TL values from the Solar Radiation Database for Environment $^{12}$ (SoDa) project website ${ }^{13}$. For each location and each month the Linke turbidity was normalized with elevation to minimize the latter's effect following equation 44 in Hofierka \& Suri (2002):

$$
T_{\text {norm }}=T+0.00035 * e
$$

where $\mathrm{T}$ is Linke turbidity, $\mathrm{T}_{\text {norm }}$ is the normalized Linke turbidity and e is elevation. Finally monthly LK grids were interpolated out of the corresponding column of normalized LK values using Spline interpolation with tension (Suri et al., 2005). Since both v.surf.rst (Suri et al., 2005; Mitasova \& Mitas, 1993; Mitasova \& Hofierka, 1993) and ArcMap have splines with tension as central to the interpolation method $^{14}$, both methods were run and compared. Within ArcMap, cross validation and a comparison with Interpolation by kriging were carried out to verify that splines work the best. 70 out of 99 locations were selected randomly for 'seeding' interpolation, both spline and kriging. Although taking the weighted average is another data fitting method that was applied for daily radiation in Switzerland and various parts of the U.S. and that was found to be only marginally different from kriging the two other methods were more strongly recommended in recent literature (Beyer et al., 1997). The spline method is an interpolation method that estimates values using a mathematical function that minimizes overall surface curvature, resulting in a smooth surface that passes exactly through the input points and in the presence of tension creating a less smooth surface with values more closely constrained by the sample data range. Kriging methods, on the other hand, assume that the distance or direction between sample points reflects a spatial correlation that can be used to explain variation in the surface and fit a mathematical function to a specified number of points, or all points within a specified radius, to determine the output value for each location. The resultant grid from each method was then used to extract the 'guessed' values to the remaining 29 spots. The average error and standard deviation from cross validation with kriging e.g. January turbidity are 0.0274 and 0.0265 respectively compared to 0.0006 and 0.001 for the case of spline.

3.1.5 Ground measured values of GHI: these were collected and tabulated in the same way as were

12http://www.soda-is.com/doc/enviroinfo2002_presentation.pdf 13http://www.soda-is.com/eng/services/service_invoke/gui.php 14http://grass.itc.it/grass64/manuals/html64_user/v.surf.rst.html 
Published as: H.T. Nguyen and J.M. Pearce, "Estimating Potential Photovoltaic Yield with r.sun and the Open Source Geographical Resources Analysis Support System” Solar Energy 84, pp. 831-843, 2010. http://dx.doi.org/10.1016/j.solener.2010.02.009

the Linke turbidity data. They can be accessed from within NASA SSE database ${ }^{15}$.

3.1.6 Recommended average days for months:To reduce simulations from 365 times for 365 days to just 12, Klein's definition of mean day was applied, which defines the mean day of each month to be the day for which daily horizontal extraterrestrial irradiance is approximately the same with the mean monthly averages. Table 1.6.1 in Duffie \& Beckman (1991) readily provides the day of month, day of year and $\delta$ (sun declination) values to input into the simulation.

3.1.7 Albedo: Previous work on r.sun often took albedo to be unvarying spatially and temporally (Hofierka \& Suri, 2002; Suri et al., 2005). In fact for Canada albedo was found to be treated as a constant of 0.2 (Mottillo et al., 2006). If albedo is taken to be 0.2 and if only horizontal radiation is concerned and contains only beam and diffuse radiation (Hofierka \& Suri, 2002; Suri et al., 2005), the contribution of ground reflected radiation is negligible. However, the error created using a constant 0.2 can be substantial if ground reflectance is between 0.6 and 0.7 as typical of snow and/or if steep slopes are present (Duffie \& Beckman,1993).

As a table for Ontario's monthly albedo could not be found monthly locational albedo values can be retrieved in the same way as were ground measured horizontal irradiance from NASA SSE's regional data subsets. Alternatively a generalized list of values was presented by Olseth \& Startveit (1997), whereby surface albedo 0.15 for the snow-free season April to November, 0.25 for January and February with most frequent snow cover and 0.20 for December and March. Inferred from Beyer et al. (1997) the above list would have minimal impact on the simulation whether we included or excluded ground reflected radiation. Brest \& Goward (1987) list monthly albedo broken down for farm, forest, city and suburbs, which hence can only be used if we can classify each pixel in the region grid accordingly. Finally a rich database, readily incorporated into GIS, is available through measurements from the MODerate-resolution Imaging Spectroradiometer ${ }^{16}$. A trial incorporating albedo was run on Kingston only, which showed that beam and diffuse irradiation are in the order of kWh whereas ground reflection is in the order of Wh only. The effects of albedo on the larger region will be left for future work. Here albedo is set at 0.2 .

3.1.8 Clear sky index: the clear sky index $K c$ can be estimated by the following methods: (i) where GHI under cloudless condition and that under cloudy conditions are both available, $K c$ is simply the ratio of the latter over the former (Hofierka \& Suri, 2002); (ii) linear regression (Kasten \& Czeplak, 1979) and (iii) indirect derivation of $K c$ from cloud cover index extracted from satellite images (Martins et al., 2007). For the case of Canada, in the past precipitation was used as a surrogate for cloudiness (McKenney et al., 2008). The first method was used in this study as demonstrated in Suri et al. (2005) and as one with lowest cost, least computation and least extra data acquisition requirements.

\subsection{Simulation}

Between the two modes of operation available from r.sun, mode 2, which produces the sums of solar irradiation within a specified day for selected components of GHI month beam $_{\text {, }}$ month $_{\text {diff }}$ and month $_{\text {groundrf, }}$ was selected. Using Klein's mean day definition these values are approximations for the respective

15http:/eosweb.larc.nasa.gov/cgi-bin/sse/sse.cgi?na+s01\#s01

16 https://lpdaac.usgs.gov/lpdaac/products/modis_products_table/brdf_albedo_model_parameters/16_day_13_global_500m/ v5/combined 
Published as: H.T. Nguyen and J.M. Pearce, “Estimating Potential Photovoltaic Yield with r.sun and the Open Source Geographical

Resources Analysis Support System” Solar Energy 84, pp. 831-843, 2010. http://dx.doi.org/10.1016/j.solener.2010.02.009

components of the corresponding months. All results are in floating points, which demands that the export, import and insertion of the data had to be strictly in floating points.

The first step was to compute monthly clear sky global horizontal irradiation. A time step of 0.25 hour was used following Hofierka \& Suri (2002). Terrain and shadow effects were included. The simulated GI for each month was set to comprise only beam and diffuse radiation. Monthly ground-measured values of global horizontal radiation were retrieved for the same 99 places as that for the Linke turbidity values.

The next step was to calculate monthly real sky global horizontal irradiation, using an empirical parameter that quantifies cloud attenuation, denoted as month $h_{k c}$, which was the ratio of ground measure GHI to simulated GHI or month ghc $_{\text {/month }}$ ghs as adapted from Suri et al. (2005). Twelve rasters for Kc were created for 12 months by spline interpolating with default tension the corresponding month column in the ghc shapefile attribute table. The interpolation tool from the 3D Analyst toolbox replaced the GRASS script v.vol.rst since the latter demanded computation time and system cachet beyond what was available. Finally, the monthly GHI grid was computed:

$$
\text { month }_{g h}=\text { month }_{k c} * \text { month }_{g h c}
$$

Finally, to derive the annual yield, each month was simply multiplied by its number of days and summed up for a full year. Note that this estimate has not yet taken into account the efficiency of the system and the available land area. Both the bivariate (positional) and trivariate (three dimensional) interpolations were tested in McKenney et al. (2008) even though partial spline model was most favored, which would require the use of the costly ANUSPLIN package.

\subsection{Post-simulation}

Carriona et al. (2008) made it clear that project designers must have access to local climate and soil characteristics because site selection on a wide range of criteria optimizes installation, enhances the performance of installation, lowers transport losses and maintenance costs, and assists in controlling environmental, social and infrastructural impacts. The way to regulate site selection for large scale PV systems is by means of a carrying capacity model, which combines multi-criteria evaluation (MCE) and analytic hierarchy process (AHP) with GIS technology (Muselli et al., 1999). The methodology in site selection used here was based on this theoretical framework. However, since the primary interest is in new PV plant sites and the gross estimate of the total output a simple boolean selection was preferred over a weighted linear sum; the latter would require precise knowledge in the effect each criterion has on selecting new solar park site in practice.

Figures 2 and 3 illustrate the post-simulation processing which involves selecting the candidates for new solar PV farms based on meeting three criteria: (1) located within $2 \mathrm{~km}$ from the transmission lines, (2) having an area of at least 100 acres and (3) a slope of no more than $4 \% .{ }^{17}$ Calculating slope in terms of percentage is an option in ArcGIS's Spatial Analyst toolbox whereby the slope of a point site is computed as the percentage of rise over run, rise being the distance from the site of interest to the intersection between the plane in question and the horizontal and run being that from the intersection between the plane in question and the horizontal to the projection of the site of interest onto the

17 These criteria were established with consultation with Ontario-based solar farm developers. It should be noted that the criteria could be easily varied while still following the same algorithm for other regions with different limitations. 
Published as: H.T. Nguyen and J.M. Pearce, “Estimating Potential Photovoltaic Yield with r.sun and the Open Source Geographical

Resources Analysis Support System” Solar Energy 84, pp. 831-843, 2010. http://dx.doi.org/10.1016/j.solener.2010.02.009

horizontal. ${ }^{18}$

\section{Result and Discussion}

To interpolate 99 points using the methods of v.srf.rst and v.vol.rst the computation times are empirically estimated at 0.246 minutes and 3 minutes respectively. ${ }^{19}$ However the actual running took about 5 minutes for the former and several hours for the latter, despite all manipulations to reduce the computation cachet (e.g. avoiding segmentation, increasing tension parameter and using default values otherwise). Although the available facilities only made it possible to compare Spatial Analyst Spline interpolation and v.srf.rst the results were promising. Fig. 4 shows that the Linke turbidity grids closely fit together, so did the simulated clear sky global horizontal irradiation. The mean and standard deviation for difference between Linke turbidity interpolated by v.rsf.rst and that by ArcMap method were taken for the 5170 x 5660 cells in the grid and are shown on the left y-axis of Figure 4 . Whereas the minimum and maximum difference between GHI simulated using v.srf.rast - interpolated Linke turbidity and that using ArcMap - interpolated Linke turbidity are normalized over the latter and are shown on the right y-axis of Fig. 4.

The series of 12 maps for monthly GHI in the region show a bell curve which peaks up in the months of June and July as seen in Fig. 5 on the left y-axis. On the right y-axis of Fig. 5 the maximum and minimum monthly clear sky index is shown. Counties in the north such as Haliburton and Refrew and those in the southeast such as Peterborough and Prince Edward have the highest solar flux throughout the year as seen in Fig. 6. The contraction or expansion of the range of insolation values and that of sky clearness index coincides with the insolation values themselves being high or low. Between January and April Haliburton county enjoys the highest and very outstanding solar flux. The band of high solar flux shifts southwards from May to July and then forms a southwest fringe, which brings high insolation to Peterborough and Prince Edwards counties between August and November before concentrating on to Haliburton again.

On the other hand sky clearness index decreases as irradiation increases and vice versa. The monthly trend is not very obvious. Recall that this is the ratio of simulated over ground measured GHI this implied that simulation closely follows reality during the summer months. These trends would have been impossible to observe with a coarser resolution while using a finer pixel size could have made the use of other methods much more bulky and inefficient. Increase in pixel size from $90 \mathrm{~m}$ to $1000 \mathrm{~m}$ turned out to improve the insolation values by merely the order of at most $0.001 \mathrm{kWh}$ per $\mathrm{m}^{2}$ per day, but escalated the computation time from several seconds to ten minutes per simulation. Elevations extracted from either resolution for the same location are very similar. Insolation was found to not correlate with either elevation or population density.

In terms of annual mean daily global horizontal irradiation, the simulation estimated it to be $3.57 \mathrm{kWh}$ per day per $\mathrm{m}^{2}$. The corresponding results from NASA SSE database and the Great Lakes Forestry $\operatorname{Center}^{20}$ (GLFC) are approximately 4.0 and between 4.2 and $5.0 \mathrm{kWh} / \mathrm{m}^{2}$ per day respectively. Annual

18 http://webhelp.esri.com/arcgisdesktop/9.2/index.cfm?TopicName=Calculating_slope

19 http://grass.osgeo.org/wiki/RST_Spline_Surfaces\#Computational_time_needed

20 Natural Resources Canada (NRCan). (2007). PV Potential and Insolation (www page). URL https://glfc.cfsnet.nfis.org/mapserver/pv/pvmapper.phtml?

MapSize $=500 \% 2 C 500 \&$ ViewRegion=Quick+Zoom\&minx=-

2508487.000000\&miny=5139927.500000\&maxx $=3080843.000000 \& \operatorname{maxy}=10729257.500000 \&$ imagewidth=500\&imagehe 
Published as: H.T. Nguyen and J.M. Pearce, “Estimating Potential Photovoltaic Yield with r.sun and the Open Source Geographical

Resources Analysis Support System” Solar Energy 84, pp. 831-843, 2010. http://dx.doi.org/10.1016/j.solener.2010.02.009

PV potential yield was estimated to be $980 \mathrm{kWh}$ per $\mathrm{kW}$ from the simulation and between 1,100 and 1,300 kWh per kW (McKenney et al., 2008). The error band for annual mean daily GHI, computed as:

$$
\text { error }=(\text { rsim }- \text { exsim }) * 100 / r s i m
$$

where rsim denotes simulation results by r.sun and exsim for results simulated externally from SSE and GLFC. The error was determined by Eq. 3 to be between $12 \%$ and $40 \%$ for both SSE and GLFC, both of which uses $10 \mathrm{~km}$ resolution. That means the smallest information holding unit for either simulation is a $10 \mathrm{~km}$ by $10 \mathrm{~km}$ square grid, which does not allow tracking changes in digital elevation anywhere within an area smaller than $100 \mathrm{~km}^{2}$. Lower information density per unit area results in a less precise terrain effect modeling e.g. shadow and hence an overestimate of GHI (Cebecauer et al., 2007). Another factor is the typical PV system being considered. Cebecauer et al. (2007) tested the sensitivity of fixed angle and two axis tracking systems against a range of resolutions from $100 \mathrm{~m}$ to $3000 \mathrm{~m}$ and found that overestimation in yearly electricity yield by $8.2 \%$ for the former system and $15.2 \%$ for the latter one. To be both accurate and conservation we would recommend using lower values in GHI estimates.

Filtering through criteria on land use, grid connection and slope reduced the available land for solar farm development in the case study of the RER (Fig. 6) to a total of 935,000 acres (Fig. 7). The result was extremely conservative in its use of only the lowest graded soil types, its limited consideration for grid connected ground mounted PV systems and strict site conditions. Plenty area with high GHI was filtered out through these criteria, which can always be relaxed in future for better scenarios. The solar farms that are under construction in Ontario and of significant capacity are located in West Carleton ${ }^{21}$ (200 acres, 20 MW); Sault Sainte Marie ${ }^{22}$ phase II (500 acres, 40 MW) and Sarnia ${ }^{23}$ (1,100 acres, 80 MW). Although the latter two are located in northern and southwestern Ontario they provide an overview of the area efficiency of solar farms in the region, which is defined as the area required to produce $1 \mathrm{MW}$ in rated peak power. It would be of interest to know how the land efficiency fluctuates throughout the year if only real time data from regional operating solar farms can be obtained.

Assuming the lowest land efficiency ${ }^{24}$, which is $10 \mathrm{~kW}$ per acre of the West Carleton farm (and also the most geographically relevant case), and given the rounded down 900,000 acres of available land, the RER can house at least 4,500 solar farms identical to West Carleton. In total the RER could thus supply $90,000 \mathrm{MW}$ or $90 \mathrm{GW}_{\mathrm{P}}$ using only marginal land and very conservative estimates. If we further assume $1,200 \mathrm{kWh}$ of output per $\mathrm{kW}_{\mathrm{AC}}$ of solar PV installed, the potential generation is 108,000 GWh (CanSIA, 2008a). Given the current annual electricity demand in Ontario of 130,000 GWh growing to 192,000 GWh in 2025 and the current goal of adding 16,000 MW or 19,200 GWh in electricity

\footnotetext{
ight=500\&CMD=ZOOM_IN\&CMD=ZOOM_IN\&CHKBOX\%5B4240\%5D=4240\&CHKBOX $\% 5 B 2057 \% 5 \mathrm{D}=2057 \& \mathrm{CHKBOX \% 5B2701 \% 5D=2701 \& CHKBOX \% 5B2700 \% 5D=2700 \& CHKBOX}$

\%5B92163\%5D=92163\&units=1\&tilt=5\&period=13\&title=PV+potential+and+insolation\&title_e=PV+potential+and+insol ation\&title_f=Potentiel+photovolta

\%EFque+et+ensoleillement\&NEK=e\&LAYERS=2700\%2C2701\%2C2057\%2C4240\&SETS=1707\%2C1708\%2C1709\%2C $1710 \% 2 \mathrm{C} 1122 \& R L A Y E R=92163$

21 http://www.canada.com/Ottawa+area+solar+farm+gets+thumbs+from+residents/1784824/story.html

22 http://www.city.sault-stmarie.on.ca/contentadmin/UserFiles/File/CityDepartments/Clerks/MediaArchive/2009/Sault \%20this\%20Week/06\%2024\%20Solar.pdf

23 http://www.stcatharinesstandard.ca/ArticleDisplay.aspx?e=1677270

24 It should be noted, land efficiency is simply the power per unit area of the solar PV farm and is independent of the energy conversion efficiency of the PV panels used.
} 
Published as: H.T. Nguyen and J.M. Pearce, “Estimating Potential Photovoltaic Yield with r.sun and the Open Source Geographical Resources Analysis Support System” Solar Energy 84, pp. 831-843, 2010. http://dx.doi.org/10.1016/j.solener.2010.02.009

generation (CanSIA, 2008a) ground mounted solar PV can cover nearly 60\% of Ontario’s projected peak electricity demand in 2025 or 5.6 times the current goal for the amount of additional clean generation to Ontario's electricity system. The result is not only outstanding in terms of coal-fired electrical generation alleviation as Ontario complies with its mandate to eliminate all coal fired electricity by 2014 (Burda \& Peter, 2008), but also in terms of economic opportunities. Solar PV in Ontario, if aggressively pursued, has a potential of creating thousands of jobs and achieving grid parity between 2016 and 2020 (CanSIA, 2008a).

The site selection performed here fully obeyed the Ministry of Municipal Affairs and Housing's latest Provincial Policy Statement, section 1.8.3, which states “Alternative energy systems and renewable energy systems shall be permitted in settlement areas, rural areas and prime agricultural areas in accordance with provincial and federal requirements. In rural areas and prime agricultural areas, these systems should be designed and constructed to minimize impacts on agricultural operations." (CanSIA, 2008b). It is significant that full compliance to this freely interpretable code still leaves the RER with nearly 1 million acres for solar farm development. Few ongoing solar farm developments (e.g. the ones in South Stormont and East Hawkesbury, Stones Mills in Lennox \& Addington) are situated where the solar flux was found to be most abundant. These results could mitigate many social concerns over the impact of solar parks (e.g. sacrificing useful agricultural land to install energy farms), and thus direct more attention to appreciation of solar PV's benefits.

On the other hand these results show that where the solar flux is abundant, but where few prospective lands were found there is a need for grid upgrading if solar farms are to be developed. Also, such regions of high flux, but poor solar farm availability may be favored for distributed generation roof mounted PV systems. Thus, these same results can be utilized for utility planning. The OPA website lists the names of regions and substations that can no longer support additional generation. The RER still has significant capacity for new projects (with the exception of part of Ottawa; Stormont, Dundas and Glengarry; and Prescott \& Russell) and is positioned right beside regions with limited or no capacity in south and southwestern Ontario. The pursuit of solar energy in southeastern Ontario will thus enhance the geography of energy in Ontario and spur the regional economy. Deploying PV on such a scale can act as a demonstration of one of the first regions to adopt a more sustainable and economic 'soft energy path' in contrast to the cost overruns of the 'hard' paths under the provincial government’s initiatives (Lovins, 1977).

The inclusion of albedo for Kingston alone showed that its contribution to overall GHI is minimal, where beam plus diffuse is in the order of $\mathrm{kWh}$ per day per $\mathrm{m}^{2}$ whereas that for ground reflection is in the order of Wh per day per $\mathrm{m}^{2}$. In addition, the time consumed is significant (around 30 minutes - that for the whole region is likely to be in the order of hours). In the absence of ground reflection, the city was already found to enjoy more abundant solar flux than the average over RER.

The limitations and therefore the sources of error in this study came from the various aspects it did not address. The first is estimation of PV yield on tilted planes. This can be done in r.sun as demonstrated in Hofierka \& Suri (2002) and Suri et al. (2005) with two separate sky clearness indices for beam and diffuse components. Archived data for diffuse radiation at selected location are available at SoDa and SSE. However, in order to use this additional information the type of solar cell modules becomes 
Published as: H.T. Nguyen and J.M. Pearce, “Estimating Potential Photovoltaic Yield with r.sun and the Open Source Geographical Resources Analysis Support System” Solar Energy 84, pp. 831-843, 2010. http://dx.doi.org/10.1016/j.solener.2010.02.009

important and the modeling is better dealt with using a simulation package specialized for PV system design (e.g. PVSyst). This work, which will be left for the future, would enable the inclusion of 'secondary order' effects of temperature and low light conditions, which are system specific and therefore better addressed by a model with explicit information on PV module components and technology type (McKenney et al., 2008).

The algorithm developed here was only partially open source and thus openly accessible to all researchers. This can be overcome to be a process using only open software pending the development of the following functions in GRASS the ability to: (1) recognize more formats of DEM files such as bil and hdf; (2) to convert between rasters and shapefiles and between lines and points; (3) to manipulate rasters in ways other than arithmetic operations (e.g. stack RGB, mosaic and extract values to points).

Ineichen \& Perez (2002) proposed a new formulation for Linke turbidity that is solar altitude independent, but still matches the original values at air mass $=2$ and hence promises to be coherent with previous studies that were done with the old formulae (Karsten, 1980). If this can be verified it will help extend the application of r.sun and in particular the use of Linke turbidity since to be air mass independent is to be less location independent. More work is required for the case of Canada since the method was developed without any Canadian data. Finally, further work is needed to consider tilted planes via the use of a simulation model and distributed PV systems and to include the economic feasibility of these potential tracts.

\section{Conclusions}

A complete algorithm was presented covering the steps of data acquisition and preprocessing to post simulation whereby candidate lands for incoming solar farms projects can be identified for any region in the world. It was found that r.sun provides a partial open source, relatively non-computation intensive, but still high handling capacity means to model solar energy for large-scale photovoltaic system planning. For the first time the package r.sun within the open source GIS software package GRASS was used to compute insolation and photovoltaic yield for a case study in Canada. This was done for the Renewable Energy Region, in Southeastern Ontario. It was confirmed that Ontario had a large potential to push forward renewable energy, in particular solar energy.

\section{Acknowledgments:}

The authors would like to acknowledge helpful discussions with G. McQuat, A. Wolf and C. Kutscher and support from the Natural Sciences and Engineering Research Council of Canada.

\section{Nomenclature}

$\begin{array}{ll}\text { AHP } & : \text { Analytic Hierarchy Process } \\ \text { CLI } & : \text { Canadian Land Inventory } \\ \mathrm{CO}_{2} & : \text { Carbon dioxide } \\ \mathrm{CSD} & : \text { Census Subdivision }\end{array}$




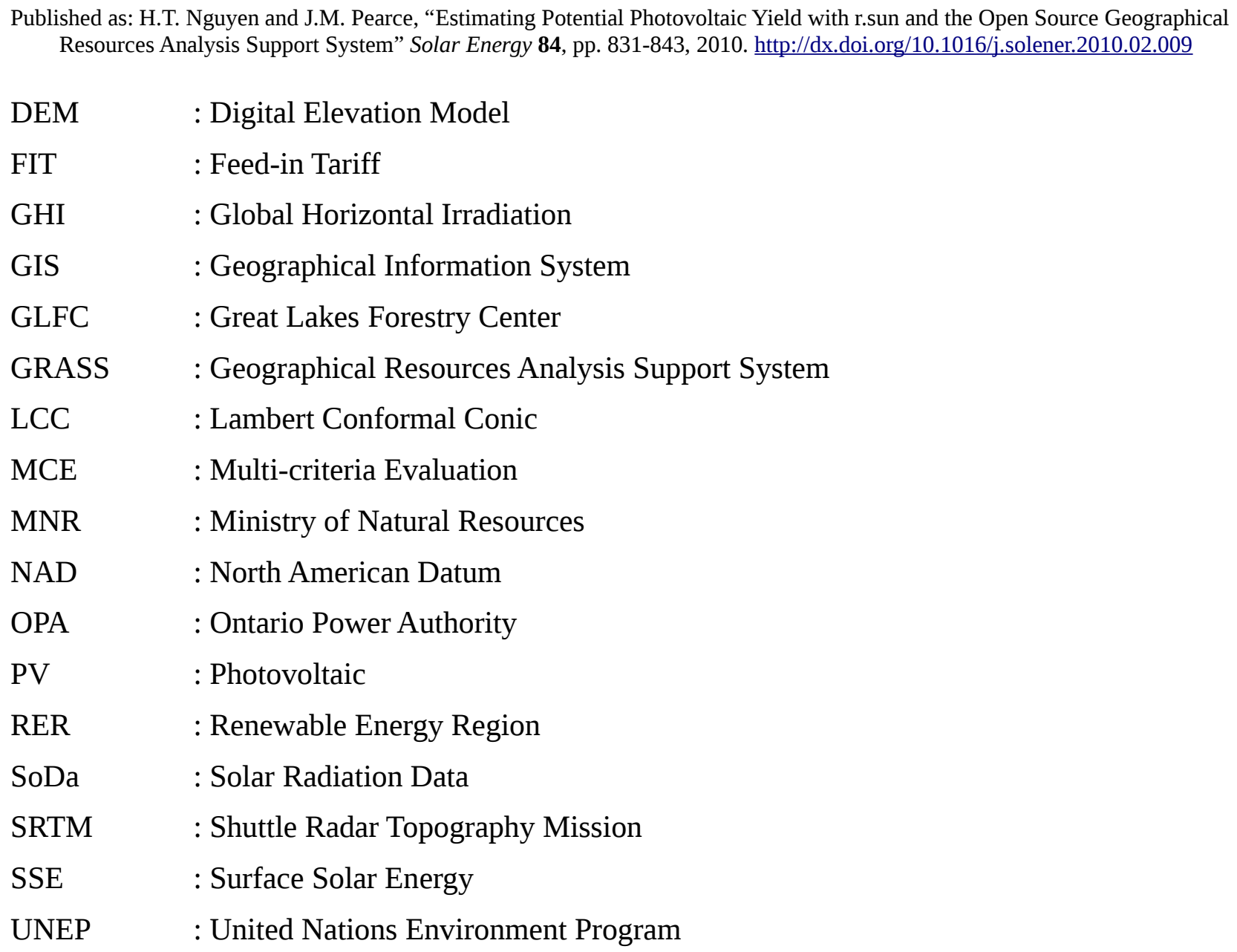


Published as: H.T. Nguyen and J.M. Pearce, "Estimating Potential Photovoltaic Yield with r.sun and the Open Source Geographical Resources Analysis Support System” Solar Energy 84, pp. 831-843, 2010. http://dx.doi.org/10.1016/j.solener.2010.02.009

\section{References}

Asif, M., Muneer, T., 2007. Energy supply, its demand and security issues for developed and emerging economies. Renewable and Sustainable Energy Reviews. 11, 1388 - 1413.

Beyer, H.G., Czeplak, G., Terzenbach, U., Wald, L., 1997. Assessment of the method used to construct clearness index maps for the new European solar radiation atlas (ESRA).Solar Energy. 61, 6, 389 - 397.

Brest, C.L., Goward, S.N., 1987. Deriving surface albedo measurements from narrow band satellite data. International Journal of Remote Sensing. 8, 3, 351 - 367.

Burda, C., Peters, J., 2008. Plugging Ontario Into a Green Future. [www page] URL http://pubs.pembina.org/reports/plugging-in-ontario-report.pdf.

Canadian Solar Industry Association (CanSIA), 2008a. Solar PV in Ontario: a Roadmap for Success. Ottawa, Ontario.

Canadian Solar Industry Association (CanSIA), 2008b. Barriers to Solar PV Development in Ontario. Ottawa, Ontario.

Carriona, J.A., Estrelaa, A.E., Dolsa, F.A., Torob, M.Z., Rodriguez, M., Ridaob, A.R., 2008a. The electricity production capacity of photovoltaic power plants and the selection of solar energy sites in Andalusia (Spain). Renewable Energy Review. 33, 545-552.

Carriona, J.A., Estrelaa, A.E., Dolsa, F.A., Torob, M.Z., Rodriguez, M., Ridaob, A.R., 2008b.

Environmental decision-support systems for evaluating the carrying capacity of land areas: Optimal site selection for grid-connected photovoltaic power plants. Renewable and Sustainable Energy Reviews. $12,2358-2380$.

Cebecauer T., Huld T., Šúri M., 2007. Using high-resolution digital elevation model for improved PV yield estimates. Proceedings of the $22^{\text {nd }}$ European Photovoltaic Solar Energy Conference, Italy, pp. 3553-3557.

Chrysoulakis, N., Diamandakis, M., Prastacos, P., 2004. GIS Based Estimation and Mapping of Local Level Daily Irradiation on Inclined Surfaces. "7th AGILE Conference on Geographic Information Science" 29 April-1May 2004, Greece Parallel Session 7.1- "Remote Sensing II".

D’Agostino, V., Zelenka, A., 1992. Supplementing solar radiation network data by co-Kriging with satellite images. International Journal of Climatology. 12, 7, 749 - 761.

Department of Energy and Semiconductor Research (EHF), University of Oldenburg. 2002. EnergySpecific Solar Radiation Data from Meteosat Second Generation (MSG): The Heliosat-3 project. Midterm progress report.

Doyle, D., Pearce, J.M. 2009. Utilization of Virtual Globes for Open Source Industrial Symbiosis. Open 
Published as: H.T. Nguyen and J.M. Pearce, “Estimating Potential Photovoltaic Yield with r.sun and the Open Source Geographical Resources Analysis Support System” Solar Energy 84, pp. 831-843, 2010. http://dx.doi.org/10.1016/j.solener.2010.02.009

Environmental Sciences. 3, pp. 88-96.

Duffie, J.A., Beckman, W.A., 1991. Solar Engineering of Thermal processes, Second ed. John Wiley \& Sons.

Earth Resources Observation and Science (EROS) Center. GTOPO30 Documentation. [www page] URL http://dds.cr.usgs.gov/srtm/version1/SRTM30/GTOPO30_Documentation

Earth Resources Observation and Science (EROS) Center. SRTM3 Documentation. [www page] URL http://dds.cr.usgs.gov/srtm/version1/SRTM30/SRTM30_Documentation

Enting, I.G., Wigley, T.M.L., Heimann, M., 1994. Future Emissions and Concentrations of Carbon Dioxide: Key Ocean/ Atmosphere/ Land Analyses. Commonwealth Scientific and Industrial Research Organization (CSIRO) Division of Atmospheric Research Technical Paper no. 31.

German Advisory Council on Global Change (WGBU). Solving the climate dilemma: The budget approach. German Advisory Council on Global Change (WBGU) Special Report 2009.

Hofierka, J., Šúri, M., 2002. The solar radiation model for Open source GIS: implementation and applications. Proceedings of the Open source GIS - GRASS users conference, Italy.

Houghton, J.T., Filho, L.G..M., Griggs, D.J., Noguer, M. (Eds), 1997. IPCC Technical paper IV: Implications of Proposed CO2 Emissions Limitations. IPCC, Geneva, Switzerland.

Huld, T.A., Šúri, M., Dunlop, E.D., 2002. GIS-based Estimation of Solar Radiation and PV Generation in Central and Eastern Europe. Preprint from the Conference "Photovoltaics in Europe: From Photovoltaic Technology to Energy Solutions". Italy.

Huld T.A., Suri, M., Dunlop, E.D., Albuisson, M., Wald, L., 2005. Integration of Helioclim I databse into PV GIS to estimate solar electricity potential in Africa. Published in the Proceedings from 20th European Photovoltaic Solar Energy Conference and Exhibition, Spain.

Hutchinson, M.F., Booth, T.H., McMahon, L.P., Nin, H.A., 1984. Estimating monthly mean values of daily total solar radiation for Australia. Solar Energy. 32, 277 - 290.

Ineichen, P., Perez, R., 2002. A new air mass independent formulation for the Linke turbidity coefficient. Solar Energy. 73, 3, 151 - 157.

International Energy Agency (IEA), 2008. Key World Energy Statistics. International Energy Agency. Paris, France: OECD Publication Service.

Kasten, F., Czeplak, G., 1979. Solar and terrestrial radiation dependent on the amount and type of cloud. Solar Energy. 24, 2, 177 - 189.

Karsten, F., 1980. A simple parameterization of the pyrheliometric formula for determining the Linke 
Published as: H.T. Nguyen and J.M. Pearce, "Estimating Potential Photovoltaic Yield with r.sun and the Open Source Geographical Resources Analysis Support System” Solar Energy 84, pp. 831-843, 2010. http://dx.doi.org/10.1016/j.solener.2010.02.009

turbidity factor. Meteorologische Rundschau. 33, 124 - 127.

Keppler, J.H., 2007. International relations and security of energy supply: risk to continuity and geopolitical risks. [www page] URL http://foltynkubicka.com/img/stuff/Opracowanie\%20Keppler.pdf

Kilian, L., 2008. The Economic effects of energy price shocks. Journal of Economic Literature. 46, 4, $871-909$.

Louche, A., Peri, G., Iqbal, M., 1986. An analysis of Linke turbidity factor. Solar Energy. 37, 6, 393 396.

Lovins, A.B., 1977. Soft Energy Paths: Toward a Durable Peace. Penguin Books, Harmondsworth, Middlesex, UK.

Mabee, W., Mirck, J., Carpenter, T., McKechnie, J., Zhang, Z., MacLean, H., 2009. Energy from Biomass in Ontario: Getting Beyond the Promise. [www page]. URL http://www.queensu.ca/qieep/conference2/presentations/Warren\%20Mabee,\%20QIEEP.pdf

Martins, F.R., Pereira, E.B., Ebreu, S.L., 2007. Satellite-derived solar resource maps for Brazil under SWERA project. Solar Energy. 81, $517-528$.

McKenney, D.W., Pelland, S., Poissant, Y., Morris, R., Hutchinson, M., Papadopol, P., Lawrence, K., Campbell, K., 2008. Spatial insolation models for photovoltaic energy in Canada. Solar Energy. 82, $1049-1061$.

Metz, B., Davidson, O.R., Bosch, P.R., Dave, R., Meyer, L.A. (eds), 2007. Contribution of Working Group III to the Fourth Assessment Report of the Intergovernmental Panel on Climate Change. Cambridge University Press, Cambridge, United Kingdom and New York, NY, USA.

Mitasova, H., Mitas, L., 1993. Interpolation by Regularized Spline with Tension: I. Theory and Implementation. Mathematical Geology. 25(6), 641-655.

Mitasova, H., Hofierka, J., 1993. Interpolation by Regularized Spline with Tension: II. Application to Terrain Modeling and Surface Geometry Analysis. Mathematical Geology. 25(6), 657-669.

Mottillo, M., Morrison, I.B., Couture, L., Poissant, Y, 2006. A comparison and validation of 2 Photovoltaic models. CanmetEnergy [www page] URL http://canmetenergy-canmetenergie.nrcanrncan.gc.ca/eng/buildings_communities/buildings/pv_buildings/publications/2006237.html

Muselli, M., Notton, G., Poggi, P., Louche, A., 1999. Computer aided analysis of the integration of renewable energy systems in remote areas using a geographical information system. Applied energy. 63, 3, $141-160$.

Nakicenovic, N., R. Swart (Eds.), 2000. IPCC Special Report on Emissions Scenarios. Cambridge University Press, UK. 
Published as: H.T. Nguyen and J.M. Pearce, “Estimating Potential Photovoltaic Yield with r.sun and the Open Source Geographical Resources Analysis Support System” Solar Energy 84, pp. 831-843, 2010. http://dx.doi.org/10.1016/j.solener.2010.02.009

Pearce, J.M., 2002. Photovoltaics: a path to sustainable futures. Futures. 34, (7), 663-674.

Pearce, J.M., Johnson, S.J., Grant, G.B., 2007. 3D-Mapping Optimization of Embodied Energy of Transportation. Resources, Conservation and Recycling. 51, 435-453.

Pindyck, R.S., 1999. The long run evolution of energy prices. The Energy Journal. 20, 2. The International Association for Energy Economics, USA.

Olseth, J.A., Skartveit, A., 1997. Spatial distribution of photosynthetically active radiation over complex topography. Agricultural and Forest Meteorology. 86, 205 - 214.

Ontario Power Authority (OPA), 2009a. Ontario, Canada, Implements Solar Feed-in Tariff. [www page]. URL http://www.powerauthority.on.ca/Page.asp?

PageID=122\&ContentID=7094\&SiteNodeID=565

Ontario Power Authority (OPA), 2009b. Feed-in Tariff Program [www page]. URL http://www.powerauthority.on.ca/FIT/

REC Solar Inc., 2009. Innovative Turnkey Solar Power Systems in One Procurement. General Services Administration. [www page] URL https://www.gsaadvantage.gov/ref_text/GS21F0099V/0GPDUR.215AQV_GS-21F0099V_RECSOLARGS21F0099VREFORMAT3.PDF

Renewable Energy Policy Network for the 21st Century (REN 21), 2009. Renewables Global Status Report: 2009 Update. Renewable Energy Policy Network for the 21st Century. Paris: REN21 Secretariat.

Rigollier, C., Lefevre, M., Wald, L., 2004. The method Heliosat-2 for deriving shortwave radiation from satellite images. Solar Energy. 77, 2, 159 - 169.

Sims, R.E.H., 2003. Renewable energy: a response to climate change. Solar Energy. 76, 1-3, 9 - 17.

Š́ri, M., Huld, T.A., Dunlop, E.D., 2005. PV-GIS: a web-based solar radiation database for the calculation of PV potential in Europe. International Journal of Sustainable Energy. 24, 2, 55 - 67.

Šrui, M., Huld, T.A., Dunlop, E.D., Ossenbrink, H.A., 2007. Potential of solar energy generation in the European Union member states and candidate countries. Solar Energy. 81, 1295 - 1305.

University of Texas. GEO326G/386G GIS and GPS Applications in Earth Sciences. Software Tips-17. [www page] URL http://www.geo.utexas.edu/courses/371c/Labs/Software_Tips/SRTM3_import.htm

Unruh, G.C., 2000. Understanding carbon lock-in. Energy Policy. 28, 817 - 830.

Unruh, G.C., 2002. Escaping carbon lock-in. Energy Policy. 30, 317 - 325. 
Published as: H.T. Nguyen and J.M. Pearce, "Estimating Potential Photovoltaic Yield with r.sun and the Open Source Geographical Resources Analysis Support System” Solar Energy 84, pp. 831-843, 2010. http://dx.doi.org/10.1016/j.solener.2010.02.009

Watson, R.T., Zinyowera, M.C., Moss, R.H., (Eds), 1996. IPCC Technical paper I: Technologies, Policies and Measures for Mitigating Climate Change. IPCC, Geneva, Switzerland.

Wiginton, L., Nguyen, H.T., Pearce, J.M., 2010. Quantifying Rooftop Solar Photovoltaic Potential for Regional Renewable Energy Policy. Computers, Environment and Urban Systems (in press).

Zaksek, K., Podobnikar, T., Ostir, K., 2005. Solar radiation modeling. Computers \& Geosciences. 31, 233-240.

Zekai S., 2004. Solar energy in progress and future research trends. Progress in Energy and Combustion Science. 30, 367 - 416.

Zelenka, A., Czeplak, G., D'Agostino, V., Josefson, W., Maxwell, E., Perez, R., 1992. Techniques for supplementing solar radiation network data, Report No.IEA-SHCP-9D-1, International Energy Agency.

Zelenka, A., 1994. Combining METEOSAT and surface network data: a data fusion approach for mapping solar irradiation, In Proc. 10th Meteosat Scientific Users Conference, pp 515 - 520, Switzerland. 
Published as: H.T. Nguyen and J.M. Pearce, "Estimating Potential Photovoltaic Yield with r.sun and the Open Source Geographical Resources Analysis Support System” Solar Energy 84, pp. 831-843, 2010. http://dx.doi.org/10.1016/j.solener.2010.02.009

\section{Figure Captions}

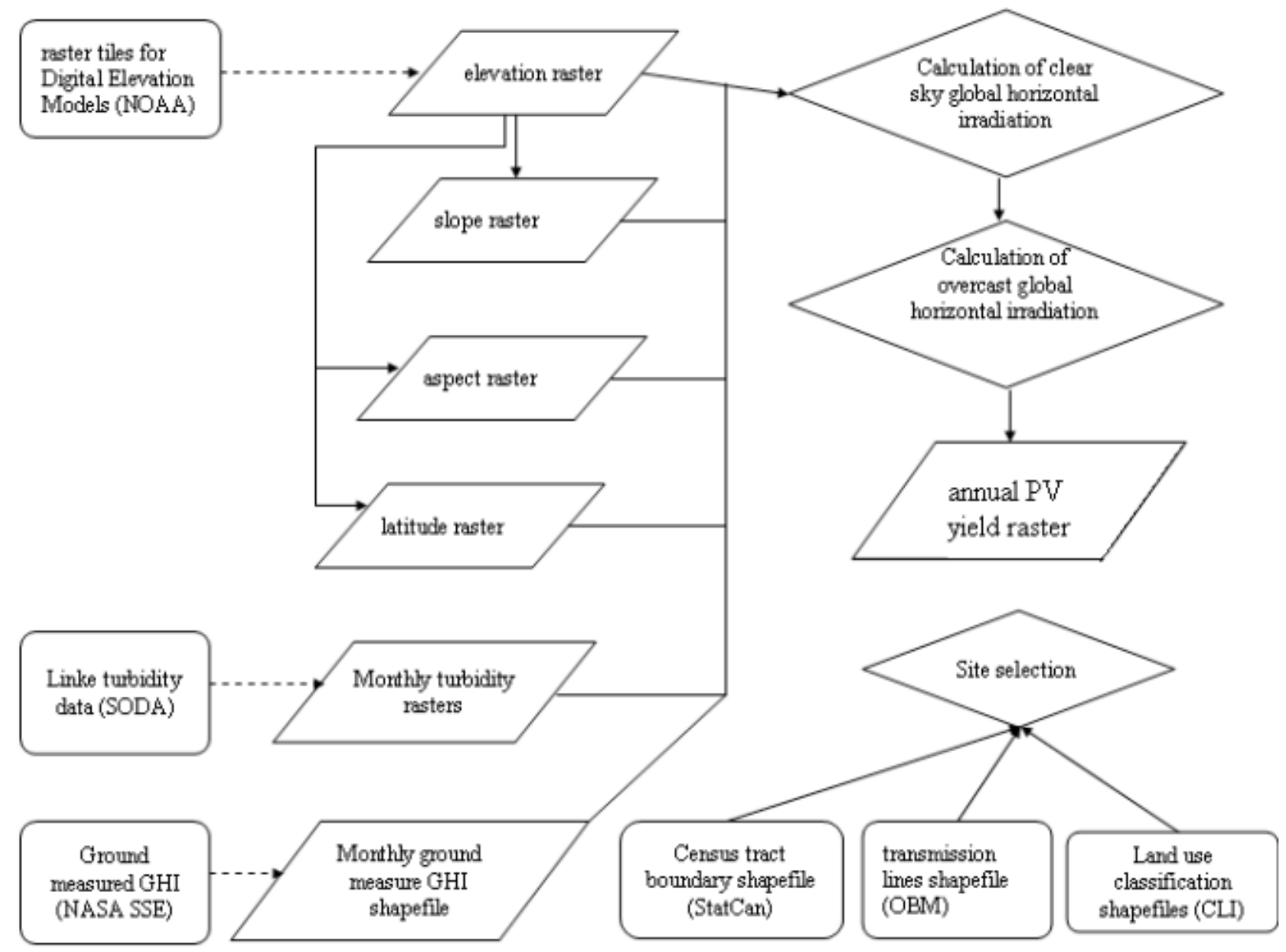

Figure 1. Work flow of the data acquisition and preparation process. Dash arrows indicate steps with multiple processes. 
Published as: H.T. Nguyen and J.M. Pearce, "Estimating Potential Photovoltaic Yield with r.sun and the Open Source Geographical Resources Analysis Support System” Solar Energy 84, pp. 831-843, 2010. http://dx.doi.org/10.1016/j.solener.2010.02.009

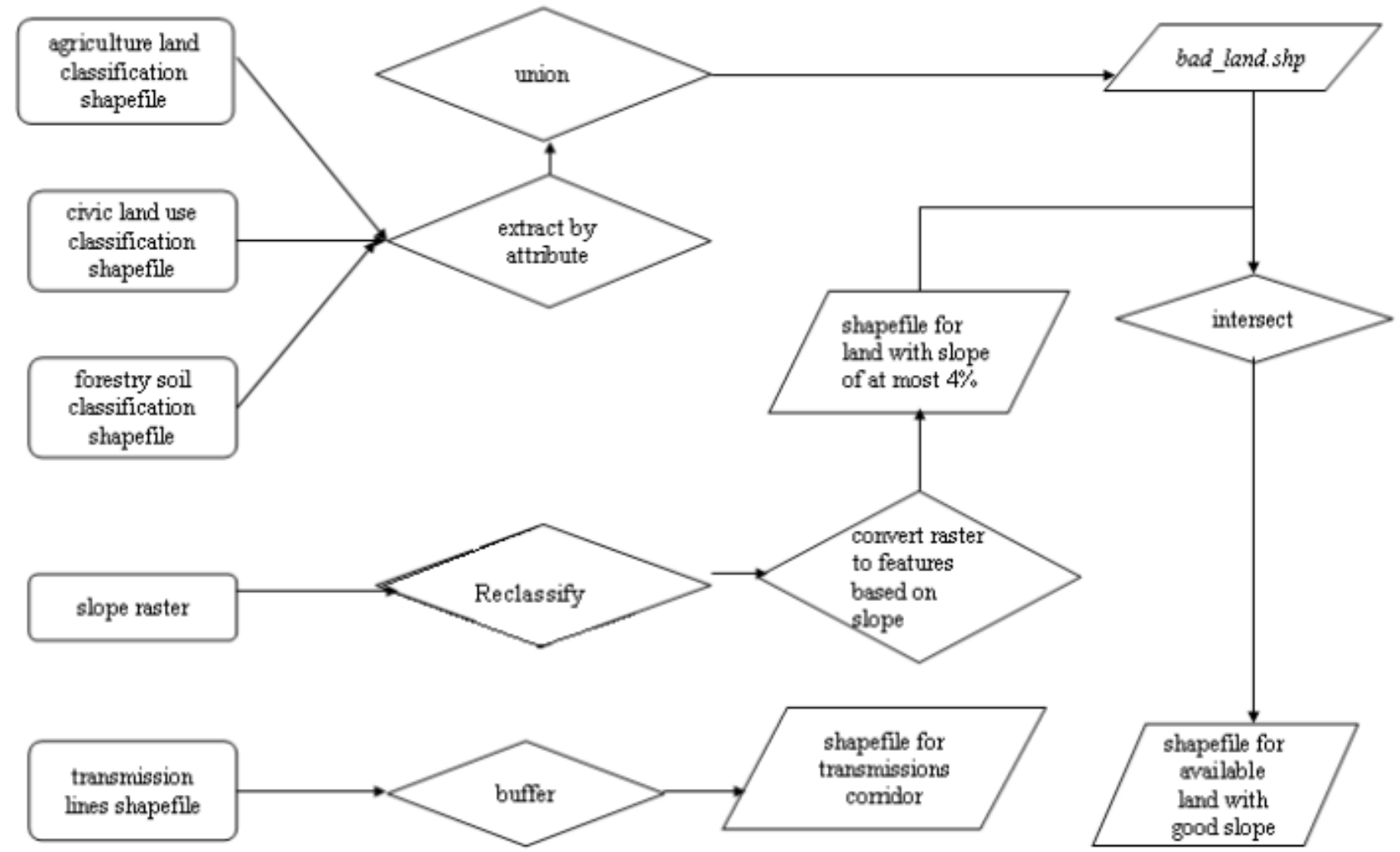

Figure 2. The work flow that establishes the extraction process for available land with good slope potential for new solar farms. 
Published as: H.T. Nguyen and J.M. Pearce, "Estimating Potential Photovoltaic Yield with r.sun and the Open Source Geographical Resources Analysis Support System” Solar Energy 84, pp. 831-843, 2010. http://dx.doi.org/10.1016/j.solener.2010.02.009

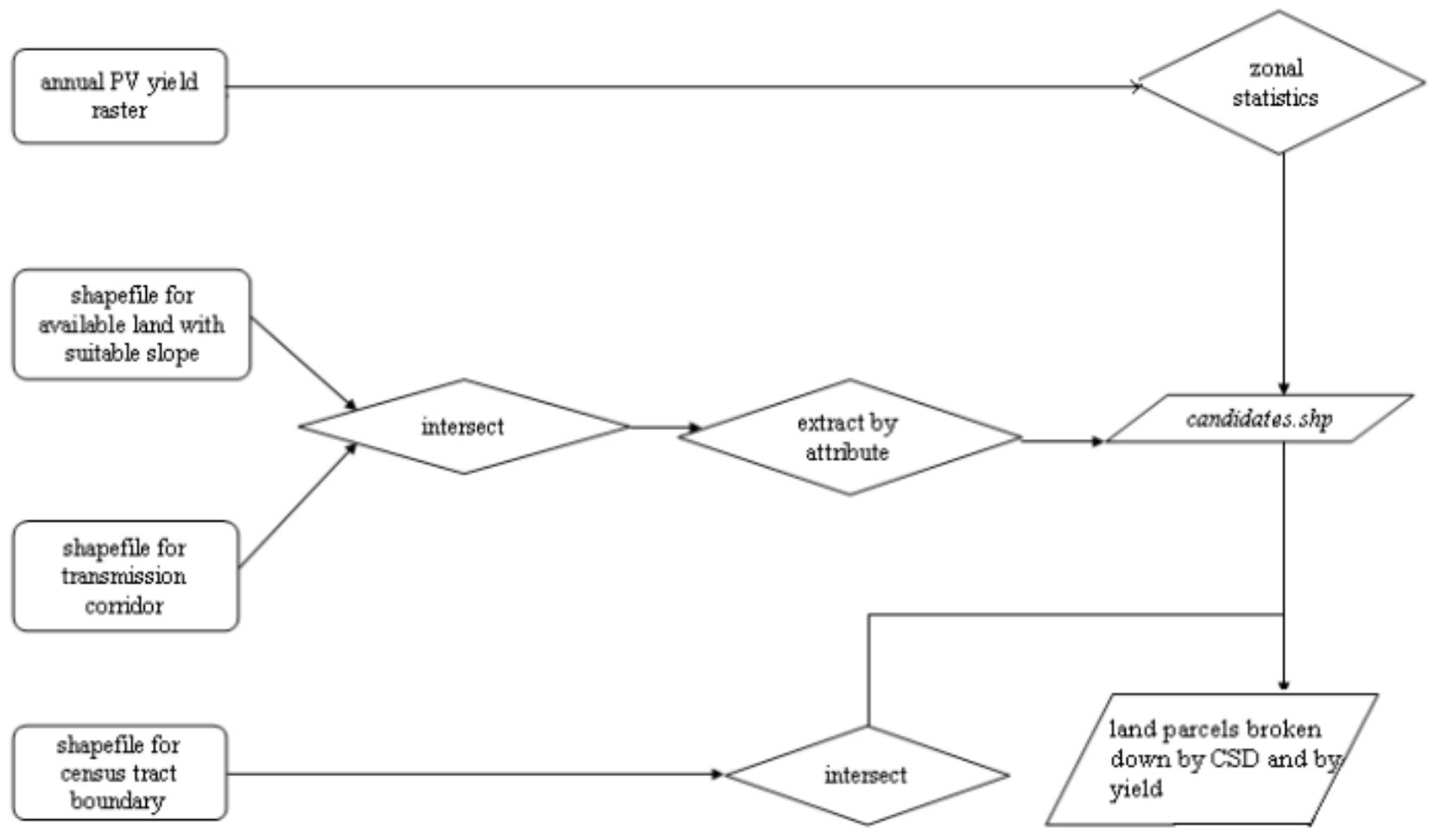

Figure 3. Work flow to calculate potential PV yield for the solar farm. 
Published as: H.T. Nguyen and J.M. Pearce, "Estimating Potential Photovoltaic Yield with r.sun and the Open Source Geographical Resources Analysis Support System” Solar Energy 84, pp. 831-843, 2010. http://dx.doi.org/10.1016/j.solener.2010.02.009

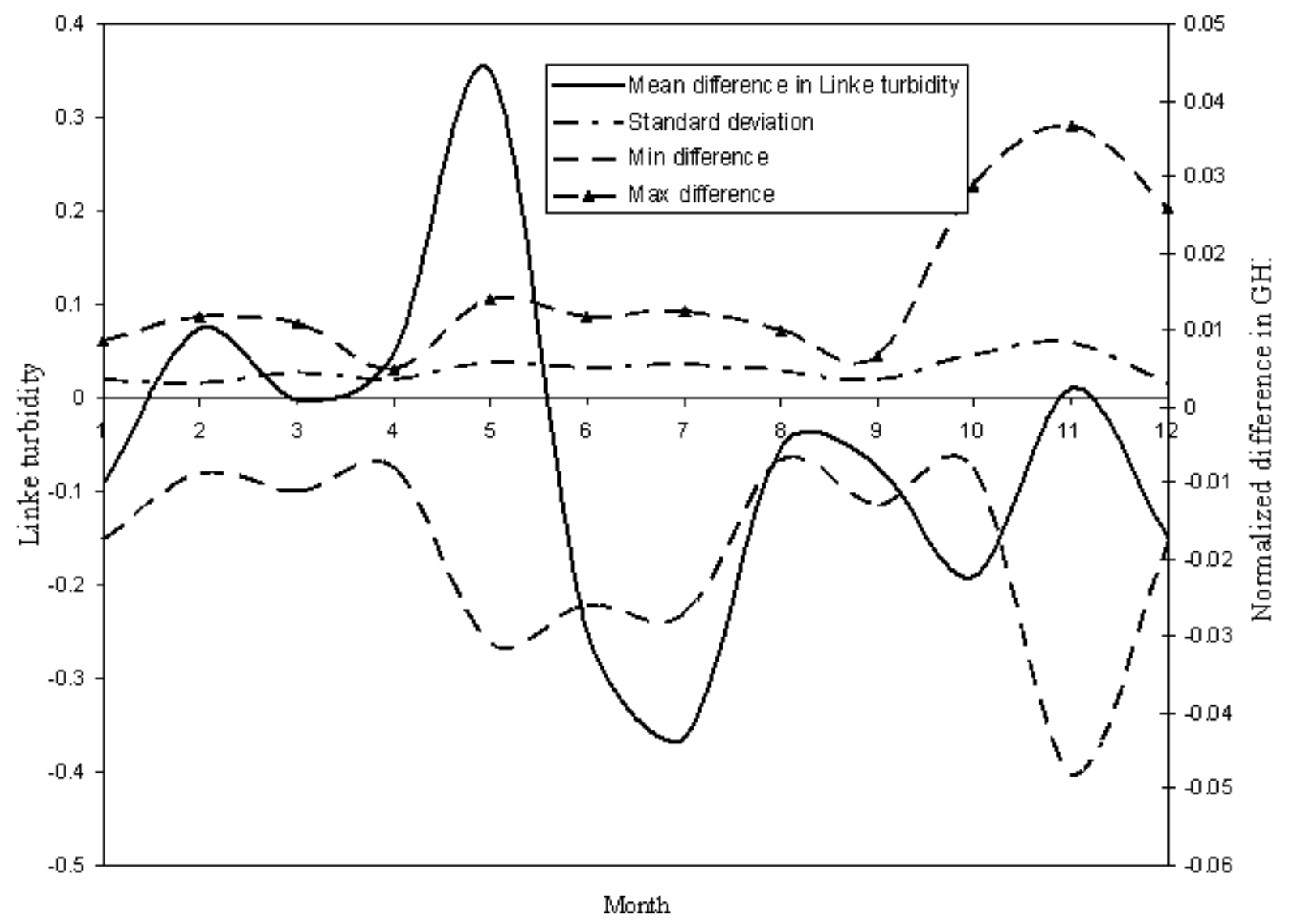

Figure 4. The mean difference between Linke turbidity interpolated with v.srf.rst and that with ArcMap (solid line) and standard deviation (dot and dashed) are both shown on the primary y axis; maximum and minimum difference between simulated clear sky GHI using either method (dash line) on the secondary y axis. 
Published as: H.T. Nguyen and J.M. Pearce, "Estimating Potential Photovoltaic Yield with r.sun and the Open Source Geographical Resources Analysis Support System” Solar Energy 84, pp. 831-843, 2010. http://dx.doi.org/10.1016/j.solener.2010.02.009

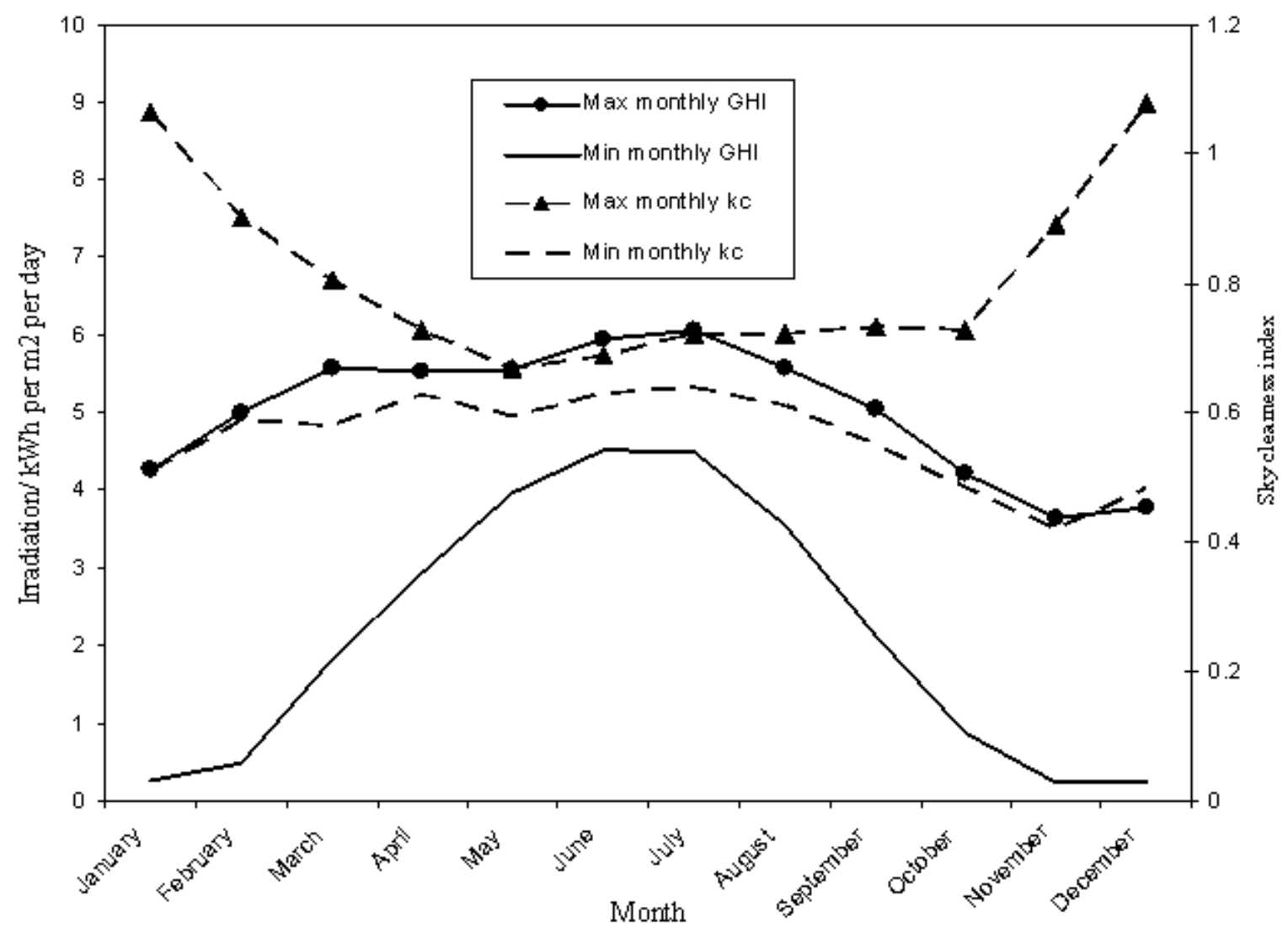

Figure 5. The minimum and maximum ranges of mean daily global horizontal irradiation (solid line) on the primary y axis and sky clearness index (dashed line) for each of month of the year on the secondary y axis. 
Published as: H.T. Nguyen and J.M. Pearce, "Estimating Potential Photovoltaic Yield with r.sun and the Open Source Geographical Resources Analysis Support System” Solar Energy 84, pp. 831-843, 2010. http://dx.doi.org/10.1016/j.solener.2010.02.009

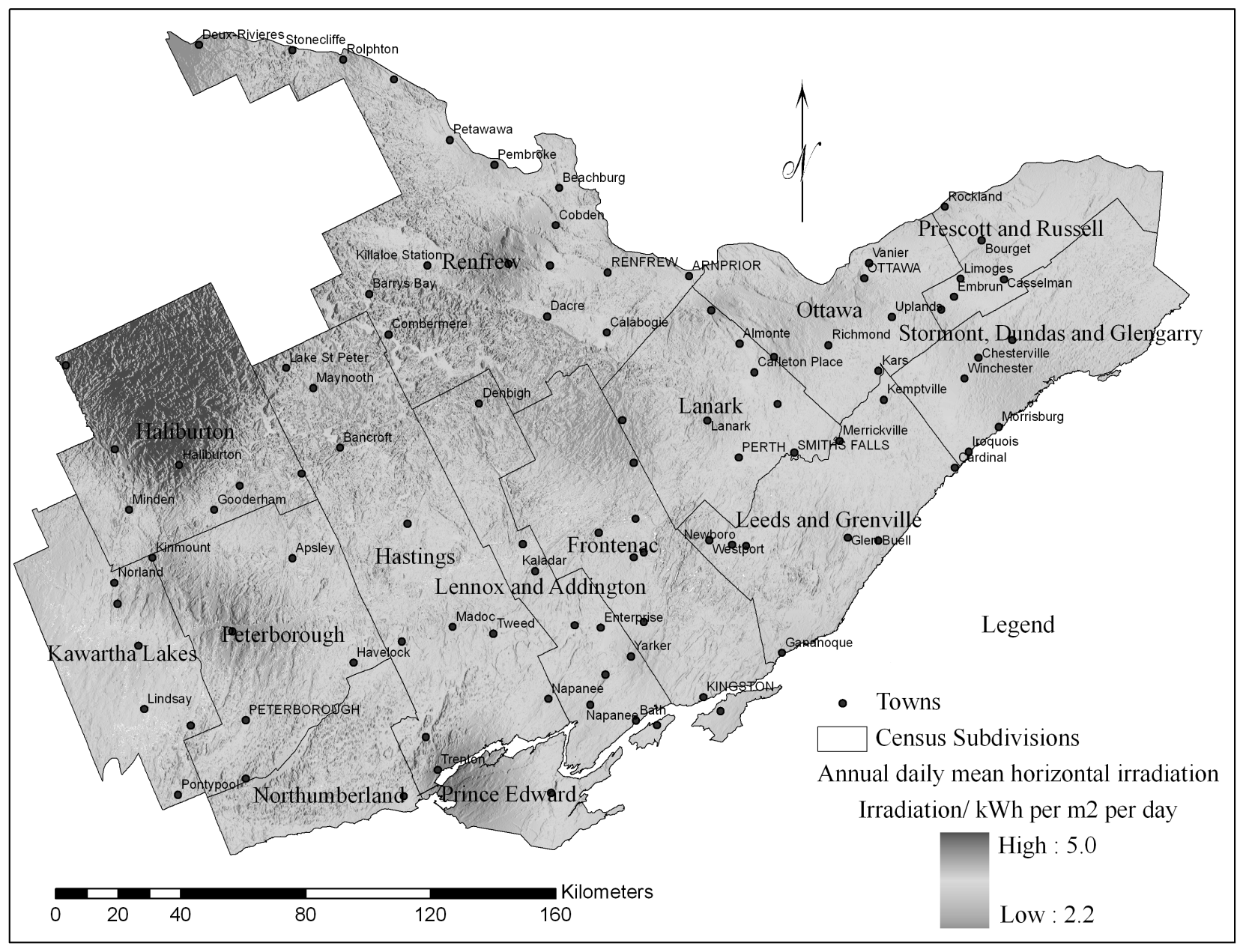

Figure 6. The annual daily mean horizontal irradiation of the Renewable Energy Region of Southeastern Ontario. 
Published as: H.T. Nguyen and J.M. Pearce, "Estimating Potential Photovoltaic Yield with r.sun and the Open Source Geographical Resources Analysis Support System” Solar Energy 84, pp. 831-843, 2010. http://dx.doi.org/10.1016/j.solener.2010.02.009

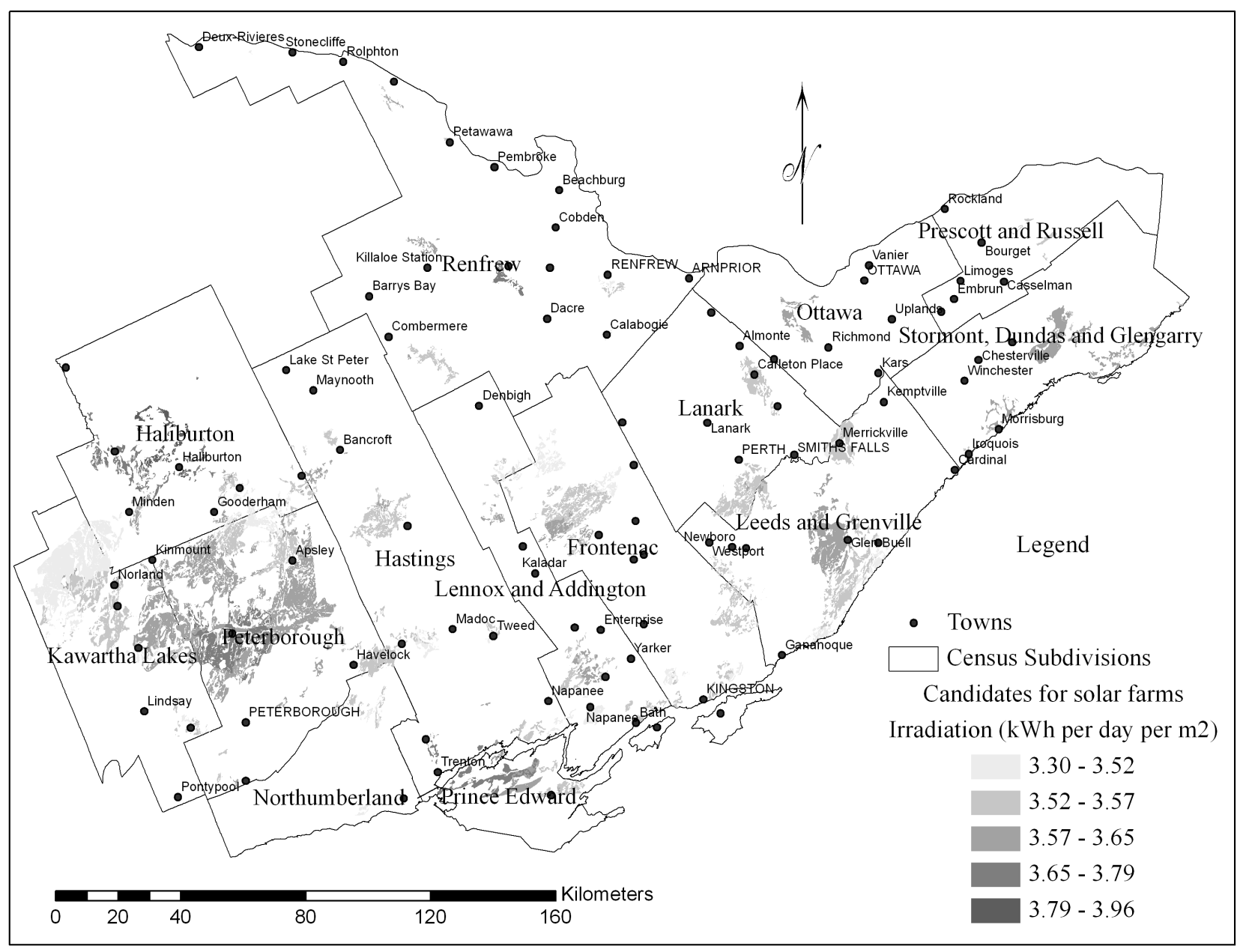

Figure 7. Potential solar farm land with their estimated insolation broken down in municipality. 